\title{
The Limit Of Age Of Marriage Is Related To The Certification Of Marriage (Study Of Early Marriage Reality In Jepara Regency)
}

\author{
Samsul Arifin ${ }^{1}$, Akhmad Khisni ${ }^{2}$, and Munsharif Abdul Chalim ${ }^{3}$
}

Abstract. The purpose of this study is to find out the background of the Marriage Worth certificate policy, the reality of early marriage and its impact in Jepara Regency and the Marriage Worth Certificate as an effort to reduce early marriage. The approach in this research is sociology juridical. Data collection methods in this study consisted of primary data obtained directly from the parties concerned. Secondary data consists of Primary legal materials and secondary legal materials namely materials that provide primary legal explanations. As an explanation, tertiary legal materials are given.

From this study it can be concluded that the background to the emergence of a Marriage Certificate policy is that divorce rates are increasing, women's reproductive health is problematic, the number of stunting children is caused by teenage mothers and increased domestic violence. Reality the number of early marriages in Jepara Regency increased significantly in 2019 3.16\% for men and $3.45 \%$ for women. From 9041 marital events dominated by the North Jepara region. The reason is also the local cultural factors that are influenced by the social system and the tradition of young marriage which is inherited in the family. While the impact of making children drop out of school, loss of reproductive rights of children due to having to get pregnant and give birth at a young age, the number of LBW that can lead to the stunting of the Marriage Right Certificate Policy as an effort to prevent early marriage, is very welcomed by various parties and religious leaders as marriage requirements for Catholicism and Hindu. In order to increase family fortune and become a sakinah, mawaddah and rahmah (mercy family).

Keywords: Marriage Age Limit; Marriage Certificate; Early Marriage.

\section{Introduction}

Marriage is the initial stage of community formation, from as forming small communities called households. Allah has created men and women to be able to relate to each other, love each other, produce offspring and live side by side in peace and prosperity in accordance with Allah's commands and the hadith of the Prophet Muhammad. ${ }^{4}$ As mentioned in the Qur'an surah Ar Ruum Verse 21.

Marriage is a spiritual bond between a man and a woman as husband and wife with the aim of forming a happy and everlasting family (household) based on the Godhead." ${ }^{5}$ The age limit for having a marriage as in Article 7 paragraph 1 of Act No. 1 of 1974 states, the age limit for a marriage is that men are 19 (nineteen) years old and women have reached 16 (sixteen) years old. ${ }^{6}$ For men under 21 years old over 19 years old, a parent's

1 Student of Master of Law, Sultan Agung Islamic University (Unissula) Semarang, email: Soeljepara12@gmail.com

${ }^{2}$ Lecturer of Faculty of Law, Sultan Agung Islamic University (Unissula) Semarang

${ }^{3}$ Lecturer of Faculty of Law, Sultan Agung Islamic University (Unissula) Semarang

${ }^{4}$ Rahman, 1996, Karakteristik Hukum Islam dan Perkawinan, PT Raja Grafindo Persada, Jakarta, p. 203.

${ }^{5}$ Hilman Kusuma, 1990, Hukum Perkawinan Indonesia, Mandar Maju, Jakarta, p. 170.

${ }^{6}$ Moh. Idris Ramulyo, SH, MH, 2004, Hukum Perkawinan Islam Suatu Analisis dari Undang-Undang Nomor 1 Tahun 1974 dan Kompilasi Hukum Islam (KHI), $5^{\text {th }}$ print, PT. Bumi Aksara, Jakarta, p. 1 
permission must be obtained, while under the age of 19 years is carried out with a religious court dispensation permit, for women under 21 years old is a parent's permission, under 16 years old is court permission. After the ratification of Act No. 16 of 2019 that the minimum age of both men and women is at least 19 years of age so it does not conflict with Act No. 23 of 2002 on Child Protection ${ }^{7}$

Early marriages, or so-called underage marriages are increasingly prevalent among Indonesian teenagers. ${ }^{8}$ The number of early marriages in Indonesia is relatively high at around $20 \%$ of the total number of marriages in each year is marriages performed by couples who are less than 19 years of age. This marriage experiences many problems in building household resilience so that it causes many factors of failure in the household. From this we will carry out research to see how the marriage age limit is associated with appropriate certification to see the reality of early marriage in Jepara Regency.

\section{Research methods}

The method of approach in this research is sociological juridical so that the law with this approach is seen in the frame of law in action which concerns the interrelation between law and social institutions ${ }^{9}$

The specification of this research is descriptive analytic method, in which the writer describes the object which is the subject of a descriptive analytic problem. The nature of this research apart from merely giving an overview of the implementation of Act No. 16 of 2019 in Jepara Regency, to see the age limit of marriage related to early marriage in Jepara Regency and the idea of a proper marriage certification

The data source consists of primary data and secondary data. Primary Data is data obtained directly from the public ${ }^{10}$ in the form of interviews with related parties 2) Secondary Data, consisting of: a) Primary legal materials and secondary legal materials. In this study the authors used the type of directed interviews (free lead). ${ }^{11}$ With non random sampling techniques (non probability sampling design). ${ }^{12}$ The sampling that the authors will interview are related parties with age restrictions on marriage and early marriage.

In the method of data analysis using qualitative analysis. Data obtained from secondary data are analyzed critically and in-depth using the content analysis method. While the primary data obtained, the authors analyze using the inductive method.

\section{Results And Discussion}

\subsection{Study of the Marriage Certificate Policy for Couples Who Will Carry Out Marriage}

The term "Marriage Certificate" became viral and came to the fore after the Coordinating Minister for PMK (Human Development and Culture) Muhadjir on Wednesday, November 13, 2019 at SICC Bogor, West Java, which will be carried out

\footnotetext{
${ }^{7}$ Sudarmo, 2005, Hukum Perkawinan, $3^{\text {rd }}$ print, Rineka Cipta, Jakarta, p. 7

${ }^{8}$ Miftah Faridh, 1990, 150 Masalah Nikah Keluarga, Gema Insani, Jakarta, p. 27

${ }^{9}$ Soejono and Abdurrahman, 2003, Metode Penelitian Hukum, $2^{\text {nd }}$ print, Rineka Cipta, Jakarta, p. 57

${ }^{10}$ Soejono, 2007, Pengantar Penelitian Hukum, $3^{\text {rd }}$ print, UI Press, Jakarta, p.51

${ }^{11}$ Soerjono Soekanto, Op. Cit., P.229

${ }^{12}$ Ibid. p. 28
} 
starting in 2020. Furthermore it is hoped that the perfection of pre-marital guidance through Eligible Marriage Certificatenot seen in terms of mandatory and not mandatory, but understood in terms of substance. Not that if you do not participate, you may not get married, but in an effort to build strong family resilience. ${ }^{13}$

This discourse, received a significant response from various parties such as the opinion of the General Treasurer Muhammadiyah Central Executive Muhammad Abbas ${ }^{14}$ National Woman Commissioner, Imam Nakha'i, also believes the same ${ }^{15}$ Minister of Women's Empowerment and Child Protection I Gusti Ayu Bintang Darmavati, ${ }^{16}$ Even Vice President Ma'ruf Amin While those who oppose this policy discourse come from politicians like Rieke Diah Pitaloka. ${ }^{17}$ Therefore, in the view of Ace Hasan Syadzily as Deputy Chairman of Commission VIII, the DPR RI advised the Government to study carefully both in terms of procedures and substance before this policy was presented before the public, especially not to burden the citizens. Likewise, it needs to be examined in terms of benefits and benefits, because marriage is included in the realm of private law $^{18}$

Whatever the pros and cons of various national figures, but the policy needs to be studied further because marriage certification is different from premarital counseling that has been run by each Regency Religious Affairs Office which only explains about the purpose of marriage, the rights and obligations of husband and wife. The factors causing the emergence of a marriage certificate are: a) Number of Family / Divorce Damages b) Lower Reproductive Health c) Number of stunting children ${ }^{19}$ d) Domestic Violence (Domestic Violence)

In spite of the polemic about the "Marriage Certificate", the Ministry of Religion has conducted a program on the Prospective Bride Course (Suscatin) as outlined in the Decree of the Minister of Religion (KMA) No.477 of 2004, Circular Letter of the Director General of Islamic Community Guidance Number DJ.II / PW.01 / 1997/2009, Regulation of the Director General of Islamic Community Guidance Number DJ.II / 5422013 About Pre-Marriage Course Guidelines which also include "Adolescent Marriage Age". Currently nationally implemented BIMWIN (Marriage Guidance) Program is appropriate Regulation of the Director General of Islamic Community Guidance No. 373 of 2017

\footnotetext{
${ }^{13}$ According to him, Worthy Marriage Certification is expected to reach 2 million new couples who get married every year in Indonesia. This is related to 1000 divorces that also occur each year. Agus explained, couples who do not follow guidance and do not get a certificate, can still get married. BecauseKemenko PMK realize that the new institutional capacity of the government can reach 10 percent of couples in Indonesia

14 Fitri Haryanti Harsono, http://www.liputan6.com/health/read/3878226

15 Maisuri Tajdudin Chalid, Sertifkasi Layak Nikah, The Importance of Upstream Health Interventions https://theconversation.com/128930 accessed March 1, 2020

${ }^{16}$ Sertifikasi Layak Nikah persiapan perkawinan bisa mencegah pernikahan dini, Abdul Basith, Tujuan Sertifikasi Pernikahan Untuk Mencegah Perkawinan Dini https://nasional.kontan.co.id/news/ accessed March 1, 2020

${ }^{17}$ Sertifikat layak Nikah dalam tataran pelaksanaannya, sehingga bias jadi banyak calon pengantin gagal menikah karena tidak memiliki sertifikat. Vina Fadhrotul Mukaromah, Pro Kontra Sertfikasi Layak Nikah, https://www.kompas.com/tren/read/2019/11/17/180509765/ accessed March 1, 2020

${ }^{18}$ Muis Sunarya, Plus Minus Bimbingan Perkawinan dan Sertifikat Layak Nikah https: //www.kompasiana.com/muissunarya/5dd3444e097f3669623f2cf2/ accessed March 1, 2020

${ }^{19}$ Saadah, Sertifikat Layak Nikah Efektifkah Untuk Mengatasi Stunting., https://kalimantanpost.com/2019/12/accessed March 4, 2020
} 
which was later refined with Regulation of the Director General of Islamic Community Guidance No 379 in $2018^{20}$. Since launching activitiesThis has become a national priority program in 2017 piloting in 16 provinces with a target of 149,646 pairs of bride and groom. Year 2018 Implementation of guidance of 149,646 pairs of bride in 34 Provinces and in 2019 Implementation of guidance of 209,257 pairs of bride in 34 Provinces Unfortunately this program has not become a mandatory pre-requisite for the marriage of each prospective bride.

\subsection{The Reality of Early Marriage in Jepara Regency and Its Impact}

\subsubsection{Reality of Early Marriage in Jepara Regency}

Early marriage, is believed to be one of the factors causing violence against women and children, as well as contributors to maternal death during childbirth because the reproductive organs of adolescent girls have not been established so that they cannot function optimally to give birth. Early marriage that drags many millennial generation. ${ }^{21}$ The cause is poverty and free association

In Central Java the average number of marriages is 300,000 each year, with the number of child marriages in 2016 occurring 3,186 marriages. 2017 as many as 3,176, in 2018 as many as 3,275 and 2019 as many as 3,707 marriages. It means that almost every year the percentage increases. ${ }^{22}$ The Jepara Branch of the Indonesian Women's Coalition is concerned about the high number of underage marriages that occur in Jepara. ${ }^{23}$ Likewise, from the report of the Ministry of Religion of Jepara Regency, early marriage is quite high ${ }^{24}$

The highest contributor to early marriages is Bangsri Sub-Regency, Kembang SubRegency, Jepara Sub-Regency, Keling Sub-Regency, Donorojo Sub-Regency. Ironically, from the area of the supplier area for early marriage in the North Jepara region from Bangsri to the far end of the Donorojo Regency. One reason is the cultural factors and social systems that are so hard in the lives of North Jepara people. So that more or less a phenomenon why parents want to have a lust for a daughter-in-law or download a

\footnotetext{
${ }^{20}$ Aim This activity is to provide comprehensive training to the participants to support the smooth work plan of the government in realizing the sakinah family through the application system and as an effort to realize accountability and orderly administration of marriage administration

${ }^{21}$ Tia Dwitiani Komalasari Peningkatan Pernikahan Dini Hambat Laju IPM https: //www.pikiranrakyat.com/nasional/pr-01310304/accessed March 7, 2020

${ }^{22}$ Interview with Muh Arifin, Head of Islamic Affairs and Sharia Development Regional Office of the Ministry of Religion in Central Java Province, interview conducted on Friday, 28 February 2020

${ }^{23}$ In 2016 the number of marriages of children who requested marriage dispensation in the Jepara Religious Court reached 117 cases and in 2017 there were 113 cases. While in 2018 there were 120 cases and up to mid-2019 there were 67 cases of Khomsanah Activists of the Indonesian Women's Coalition, Interviews were held on the day Saturday 29 February 2020

${ }^{24}$ Based on the 2018 marriage of 9845 pairs of brides who have been married there are 80 people whose age is less than 16 years, 2227 people who are less than 19 years old, 4842 people who are aged less than 20 to 25 years and 2696 are aged over 25 years. While the bridegroom as many as 72 people aged less than 19 years, 3807 people aged between 20 to 25 years and 5966 were aged over 25. Data on marriage age in 2018, Annual Report of the Islamic Community Guidance Section Office of the Ministry of Religion, Jepara Regency the data above can be concluded that the number of early marriages in Jepara Regency in 2019 experienced a very significant increase of $3.16 \%$ for men and for women by $3.45 \%$. It should be noted that until the end of October 2019,
} 
daughter-in-law. Because by carrying out the celebration means he will withdraw all donations that have been given to relatives, neighbors, relatives, friends and others. This culture has been rooted for generations since ancient times ${ }^{25}$ Kancilan Village is the largest early marriage supplier area in Kembang Regency from year to year. ${ }^{26}$ Whereas in Bangsri Regency, the cause of marriage is because of the large number of unwanted pregnancies due to promiscuity. ${ }^{27}$ Likewise in Keling and Donorojo Regencys. The rise of early marriage in Jepara Regency from the North was also conveyed by the Chairperson of the Jepara Regency Religious Court. This can be seen from the high number of dispensation permit applications in Jepara Regency. ${ }^{28}$

\subsubsection{Impact of Early Marriage in Jepara Regency}

The impact of early marriage in Jepara Regency is as follows:

- Many children drop out of school because they are less than 16 years old where they should be attending school / madrasa. ${ }^{29}$

- The loss of reproductive rights where she has to give birth at less than 20 years and her reproduction is not strong enough to give birth

- Number of LBW (Low Birth Weight) due to lack of nutrition knowledge of pregnant women so that AKA (Child Mortality Rate) often occurs. ${ }^{30}$

\subsection{Marriage Eligibility Certificate Efforts to Build Family Resilience and Prevent Early Marriage}

The policy delivered by the Coordinating Minister for Human Empowerment and Culture late last year really caught the public's attention, especially the actual conversation among the bride and groom. This policy concerns the benefit of the people according to the rules of the Fiqh proposal there are also the following rules:

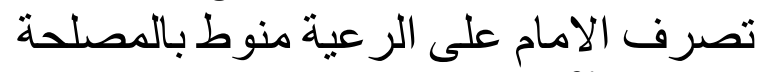

Meaning: The leader's policy for his people is based on benefit considerations ${ }^{31}$

The Marriage Certificate Policy needs to be formulated in a clear concept with a legal umbrella as to whether the model will be applied later and which Ministry should be responsible. This concerns the lives of a large majority of Muslims in Indonesia with a

\footnotetext{
${ }^{25}$ Interview with Lukman Hakim, Kancilan Village, Kembang Subdistrict, the interview was held on Sunday, March 1, 2020. This social system still applies in rural areas throughout the North Jepara area.

${ }^{26}$ Not all of the Kancilan children who get married early are caused by accidents in advance (due to promiscuity), there are indeed one or two, but on average they are asked if they do not want to go to school, who already want to get married. The search for having a marriage turns out that there is a culture of early marriage that has strengthened in their families. His mother also married when he was young.

${ }^{27}$ Interview with M Zainuddin, Head of KUA Kec Bangsri, interview was held on Sunday, March 1, 2020

${ }^{28} \mathrm{Among}$ the reasons for filing dispensations are due to getting pregnant first and the rest parents are worried about the condition of the child and prospective daughter-in-law who are already very close and close. So the parents are better off marrying their children even at a young age. the main triggers for pregnancy outside, include family factors, technology, and excessive teenage promiscuity.

${ }^{29}$ Interview with Hindun Anisah, Caretaker of Hasyim Asyari Bangsri Islamic Boarding School, interview held on Sunday, March 1, 2020

${ }^{30}$ Riyati, Jepara District Health Office Staff, interview was held on Monday, March 2, 2020

${ }^{31}$ Abu Ishaq Ibrahim ibn Musa ibn Muhammad Al-Lakhmi Asy-Syathibi, al Muwafaqat Fi Usul al Fiqh, Ministry of Waqf, Kingdom of Saudi Arabia, Volume 1, p. 27
} 
variety of different social strata of society and education strata. Do you follow the Marriage Guidance model that has become a national program and evaluate existing programs to be more optimal in their achievement?

Meanwhile, some other religions have carried out marriage-worthy certification activities. Catholics have treatment to certify marriage for three months by involving the church to prepare young families. ${ }^{32}$ Likewise, in Hinduism similar things are also carried out with the guidance of marriages and even become pre-marital conditions. ${ }^{33}$ Catholics and Buddhists are a minority group in Indonesia.

For this reason, an in-depth study is needed whether marriage guidance is a pre-marital requirement for Muslims? If the Ministry of Religion stipulates this matter, it is necessary to prepare various means of supporting facilities, on funds, facilitators assisted in each sub-Regency by involving Islamic Extension Workers, Headers, religious leaders, community leaders, related institutions such as Puskesmas, KB counseling centers ready to implement marriage guidance.

But according to the opinion of the writer, while thinking about where the Bimwin budget is obtained, what needs to be done now is how to make people feel they need marriage guidance both before marriage, marriage age, and marriage period so that their families run harmoniously and things don't happen not wanted. If the community feels the need, then the Bimwin implementation financing scheme can be carried out jointly.

If in terms of funding it is still difficult to do, it is better to consider marriage guidance material included in the school curriculum at the final level of senior high school (SLTA / MA / SMK) and at the college end of the semester. This step is quite effective in introducing matters related to marriage which of course the material will be packaged in the right formula.

\section{Closing}

\subsection{Conclusion}

From the results of the study it can be concluded that:

- Thinking about the "Marriage Certificate" for the bride and groom who will carry out the marriage is motivated by a variety of social problems that arise and use, namely 1) divorce is increasing from year to year 2) Poor reproductive health due to childbirth for less than 20 years 3 ) The number of children stunting viz conditions of failure to thrive in the body and brain due to malnutrition for a long time. and 4) Increase in domestic violence (domestic violence)

- The reality of early marriage rates in Jepara Regency has increased significantly from year to year. As happened in $20193.16 \%$ for men and $3.45 \%$ for women. Of the total 9041 marital events. Early marriage in Jepara Regency is dominated by the North

\footnotetext{
${ }^{32}$ https://www.vivanews.com/indepth/sorot/20569-kursus-dulu-menikah-kemudian

${ }^{33}$ First in a marriage in Hinduism, their relationship must be legal. So a new partner can enjoy sexual relations if it is legal or legitimate both in religion and state law, called Paparadi. Second, to continue the good future generation, named Dharma Praja, conducts religious services. That's called Dharma Sampati. Fourth, carrying out social functions, and he became a faithful partner of husband and wife. That's called Dharma Patni https://www.vivanews.com/indepth/sorot/20569-kursus-dulu-menikah-kemudian
} 
Jepara region starting from Bangsri, Kembang, Jepara Kota, Keling and Donorojo. The cause of early marriage due to unwanted pregnancy (KTD) is also a factor of local culture that is influenced by social systems that are difficult to eliminate and the tradition of young marriage inherited in the family. The impact of early marriages makes children drop out of school, loss of reproductive rights of children because they have to get pregnant and give birth at a young age, the number of LBW (Low Birth Weight of Babies) which can result in stunting

- Decent Marriage Certificate Policy as an effort to build family resilience and prevent early marriage, is very welcomed by various parties and religious leaders, it is only necessary to find the right format because it involves the benefit of the life of the Indonesian people. Revitalizing the Bimwin program (Marriage Guidance) that has been running accompanied by prerequisites to marriage as in Catholicism and Hinduism is also good. But the Government must prepare the means of the facilities including funds.

\subsection{Suggestion}

As a contribution to this research, we submit:

- To the Coordinating Minister for PMK, please apply the Marriage Eligibility Certificate policy to be implemented not just discourse. So the guidelines and their implementation are clear

- To the Indonesian Ministry of Religion, we ask for your policy so that the Bimwin program becomes a pre-marital requirement for all brides in Indonesia

- For the bride and groom, know that marriage counseling activities are an important part of entering household life, as a provision for wading the ark

\section{References}

\section{Al-Qur'an}

The Indonesian Ministry of Religion, 2004, Al-Quran and Translations, Surabaya, Mekar

\section{Books}

[1] Abu Ishaq Ibrahim ibn Musa ibn Muhammad Al-Lakhmi Asy-Syathibi, t.th, al Muwafaqat Fi Usul al Fiqh, Ministry of Waqf, Kingdom of Saudi Arabia;

[2] Hilman Kusuma, 1990, Hukum Perkawinan Indonesia, Mandar Maju, Jakarta;

[3] Ida Bagus Mantra, 2004 Filsafat Penelitian dan Metode Penelitian Sosial, Pustaka Pelajar, Yogyakarta;

[4] Jepara Regency Office of Religion, 2018 Marriage age data, Annual Report of the Islamic Community Guidance Section;

[5] Moh. Idris Ramulyo, 2004, Hukum Perkawinan Islam Suatu Analisis dari UndangUndang Nomor 1 Tahun 1974 dan Kompilasi Hukum Islam (KHI), Bumi Aksara, Jakarta;

[6] Miftah Faridh, 1990, 150 Masalah Nikah Keluarga, Gema Insani, Jakarta,;

[7] Rahman, 1996, Karakteristik Hukum Islam dan Perkawinan, PT Raja Grafindo Persada, Jakarta,:

[8] Siti Musdah Mulia, "Menuju Undang-Undang Perkawinan Yang Adil" dalam Nasaruddin Umar dkk., Amandemen Undang-Undang Perkawinan Sebagai Upaya 
Perlindungan Hak Perempuan dan Anak, Yogyakarta, Women's Study Center (PSW) UIN Sunan Kalijaga Yogyakarta:

[9] Sudarmo, 2005, Hukum Perkawinan, Rineka Cipta, Jakarta;

[10] Soejono and Abdurrahman, 2003, Metode Penelitian Hukum, Rineka Cipta, Jakarta,;

[11] Soejono, Pengantar Penelitian Hukum, 2007, Jakarta UI Press;

[12] Suharsini Arikunto, 1998, Prosedur Penelitian Suatu Pendekatan Praktik, $9^{\text {th }}$ print, Rineka Cipta, Jakarta;

[13] Sutrisno Hadi, 1984, Metodologi Research, UGM Psychology Faculty Publisher Foundation, Yogyakarta;

\section{Articles, Papers And Journals}

[1] Abdul Basith, 25 November 2019 The Purpose of Marriage Certification To Prevent Early Marriage https://nasional.kontan.co.id/news/ accessed March 1, 2020

[2] Fitri Haryanti Harsono, December 26, 2019, Certificate of Eligible Marriage Is Not an Obstacle to Marriagehttp://www.liputan6.com/health/read/3878226/ accessed March 1, 2020

[3] Maisuri Tajdudin Chalid, 27 December 2019 Marriage Certification, the Importance of Upstream Health Interventionshttps://theconversation.com/128930 accessed March 1, 2020

[4] Muis Sunarya, 30 November 2019, Plus Minus of Marriage Guidance and Marriage Eligibility https://www.kompasiana.com/muissunarya/5dd3444e097f3669623f2cf2/ accessed March 1, 2020

[5] Saadah, 27 December 2019, Certificate of Eligible Marriage Effective for Overcoming Stunting.https://kalimantanpost.com/2019/12/accessed March 4, 2020

[6] Vina Fadhrotul Mukaromah, December 9, 2019, Pros and Cons of Marriage Certification,https://www.kompas.com/tren/read/2019/11/17/180509765/ accessed March 1, 2020

\section{Laws And Regulations}

[1] Act Number 1 of 1974 on Marriage;

[2] Act Number 23 of 2003 on Child Protection

[3] Act No. 16 of 2019 on Revision of Marriage Age

[4] Presidential Instruction No. 1 of 1991 on Compilation of Islamic Law

[5] Decree of the Minister of Religion (KMA) 477 of 2004 on Suscatin

[6] Regulation of the Director General of Islamic Community Guidance Number DJ.II / 542 of 2013 on Pre-Marriage Course Guidelines.

[7] Regulation of the Director General of Islamic Community Guidance No 373 of 2017 Regulation of the Director General of Islamic Community Guidance No 379 of 2018 Regarding Marriage Guidance

[8] Circular of the Director General of Islamic Community Guidance (SE Dirjen Bimas Islam) Number. DJ.II / PW.01 / 1997/2009 about thin brides-to-be. 